\title{
Molecular, Histological and Biochemical Effects of Tea Seed Cake on Hepatic and Renal Functions of Oreochromis niloticus
}

\author{
Mosleh, Y. Y. I.** and M. Afifi** \\ *Department of Aquatic Environment, Faculty of Fish Resources, Suez University, Egypt \\ ${ }^{*}$ Department of Biological Sciences, Faculty of Science, King Abdulaziz University, North Campus, PO Box 11508, \\ Jeddah, 21463, Saudi Arabia. \\ **Department of Biochemistry, Faculty of Veterinary Medicine, Zagazig University, Egypt
}

\section{Received: $11 / 11 / 2013$}

\begin{abstract}
Tea seed cake is a plant derivative with pesticide properties mainly used for eradication of unwanted fish, it easily degraded in water leaving an organic fertilizer so it is safe for the environment, this work aimed to study it's toxic effect on the widely farmed fish in Egypt; Oreochromis niloticus throughout this study its molecular, histological and biochemical effects on liver and kidney of $O$. niloticus fingerlings exposed to different concentration of tea seed cake $\left(1 / 3,1 / 10\right.$ and $\left.1 / 20 \mathrm{LC}_{50}\right)$. There were an increase of hepatic and renal biomarkers, alanin aminotransferas (ALT), creatinin and urea concentrations in serum this concomitant with different pathological changes in hepatic and kidney tissue mainly vacuolization, degeneration, nicrosis, lymphocytic infiltration and haemolysis as well an induction of superoxid dismutas (SOD) and catalase (CAT) gene expression and increase of their activities in renal and hepatic tissues of the exposed fish.
\end{abstract}

Keywords: Tea seed cake, Biomarkers, SOD and CAT gene expression.

\section{INTRODUCTION}

Plants are virtually inexhaustible source of structurally diverse biologically active substances (Istvan, 2000). Some plants contain compounds of various classes that have insecticidal, pestcicidal and molluscicidal properties. Unlike synthetic chemical pesticides which leave harmful residues in the aquatic environment (Cagauan, 1995), botanical insecticides are believed to be more environment friendly because they are easily biodegraded with no residues in the environment the use of medicinal plants as effective alternatives of synthetic pesticides and fertilizers has gained more importance (Dahiya et al., 2000), because they are highly toxic to the target pests. Botanical pesticides are suggested as best alternatives to synthetic materials because of their easy biodegradability, easy availability, less expensive, lower toxicity against non target organisms, greater effectiveness, and their comparative safety toward the environment and human beings (Marston and Hostettmann, 1985). A large number of plant products are commonly used for controlling these unwanted fish population, such as the powdered seed of Croton tiglium and Barringtonia acutangula (Kulakkattolickal, 1989), tea seed cake and mahua oil cake (Bhatia, 1970). Plant materials such as tea seed cake or derris powder, are commonly used in Japan in shrimp culture ponds to kill selectively fish. The toxic plant products of tea seed cake and derris root powder are degraded within 7-12 days, but derris root powder is not readily available throughout the world and is also expensive (Chakroff, 1976). The residue of Camellia sp. seeds after oil extraction contains 5.2\% 7.2\% saponin (Minsalan and Chiu, 1986). Saponins are steroid or triterpenoid glycosides found in many of the potential, alternate plant-derived feed ingredients for fish, like legumes ranging between 18 and $41 \mathrm{mg} / \mathrm{kg}$ in various legume seeds; $67 \mathrm{mg} / \mathrm{kg}$ in defatted roasted soybean flour (Fenwick et al., 1991). When added to water, they are highly toxic to fish because of the damage caused to the respiratory epithelium of the gills by the detergent action of the saponins. Tea seed cake Camellia sinensis, containing about $7-8 \%$ saponins, when added to water at a dose of $100 \mathrm{ppm}$ resulted in the death of tilapia within 5 to $6 \mathrm{~h}$ (De DK et al., 1987). They are also considered to be the active components of many traditionally used fish poisons, like mahua oil cake. $1.5 \%$ in high saponin varieties could have been important contributing factors for the lower growth performance of rainbow trout (De la Higuera et al., 1988), and tilapia (Yousif et al., 1994), tea seed cake is widely used as a pesticide. The application of tea seed cake is very effective in eradicating predatory fish in prawn ponds (Terazaki et al., 1980). An application rate of tea seed cake of $15 \mathrm{mg} \mathrm{L}^{-1}$ is considered suitable (Minsalan and Chiu, 1986). Since prawn farmers often apply excess amounts of tea seed cake in pond management, the concentration of saponin in the water and its effect on the Physiological and immune systems of cultured prawn are of primary concern the 24- and 96-h LC $_{50}$ values (median lethal concentration) of saponin to shrimp, Marsupenaeus japonicas and juveniles have been reported to be 27.08 and $18.14 \mathrm{mg}$ $\mathrm{L}^{-1}$, respectively (Chen et al., 1996). Saponin has been reported to decrease the hemocyanin level and affect the acid-base balance of M. japonicus (Chen and Chen, 1996). Very little information exists on the effect of plant pesticides on pathological alterations in fish organs. Considering the reliability of histopathological lesions as biomarkers of stress in fish under toxic conditions. This research work was carried out to establish the incidence of pathological changes in key organs like the liver and kidney, as a result of long term exposure of fish to tea seed cake.

\section{MATERIALS AND METHODS}

Specimens collection:

Healthy fingerlings of Nile tilapia (Oreochromis niloticus) provided by the Fish Hatchery of Central 
Laboratory for Aquaculture Research at Abbassa, Sharkia governorate, Egypt. Two hundred and eighty fingerlings with an average body weight $40 \pm 0.1 \mathrm{~g}$ were randomly distributed. They were apparently healthy and free from any external lesions. Fish were kept in glass aquaria, each aquarium $(60 \times 50 \times 30 \mathrm{~cm})$ provided with an aerator and thermostatically controlled heater. The aquaria were filled with clean and dechlorinated water and containing tap water (temperature $26 \pm 2{ }^{\circ} \mathrm{C}$; pH $7.4 \pm 0.18$; dissolved oxygen (DO) $6.6 \pm 0.78 \mathrm{mg} / 1$; photoperiod 12:12 Light: Dark). Fish were fed on a commercial pellet diet containing $25 \%$ crude protein ( $3 \%$ of body weight per day) twice a day.

\section{Experimental design:}

A total of $80 \mathrm{O}$. niloticus fingerlings were divided into 4 groups, each group with 20 fish density in each aquarium. Three replicates were used for each concentration, the first group was kept as control, second, third and fourth groups were exposed to $1 / 3,1 / 10$

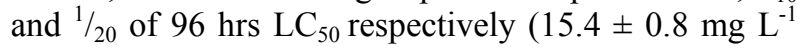
Sommai et al., 1997) of tea seed cake (soaked in water for 24 hours before use) for 8 weeks.

\section{Blood samples:}

Blood samples were collected from the caudal blood vein; blood samples for serum separation were collected without the addition of anticoagulants and then centrifuged at $3000 \mathrm{rpm}$ for $20 \mathrm{~min}$ and stored at $20^{\circ} \mathrm{C}$ until further biochemical analysis. Serum was separated for determination of alanine aminotransferase (ALT) by the method of Reitman and Frankel (1975) creatinine, (Husdan and Rapoport, 1968), urea (Chaney and Marbach, 1962), Serum superoxide oxide dismutase (SOD) activity was determined according to Packer and Glazer (1990), serum catalase (CAT) activity was determined according to the method of (Abei, 1984),

\section{Histopathological investigations:}

Specimens from the liver, kidney, were collected and fixed in $10 \%$ buffered neutral formalin solution, dehydrated in gradual ethanol concentrations (70-100\%), cleared in xylene, and embedded in paraffin. Fivemicron thick paraffin sections were prepared and then routinely stained with hematoxylin and eosin (HE) dyes besides Prussian blue stain for hemosiderosis and Von Kossa stain for calcification (Bancroft and Gamble, 2008) and then examined microscopically.

Hepatic and renal SOD and CAT gene expressions were determined using a semi-quantitative RT-PCR according to Meadus (2003). Total RNA was prepared from the frozen hepatic and renal powder using the E.Z.N.A ${ }^{\mathrm{TM}}$.spin column RNA extraction kit (Omega Bio-Tech, Cat NO R6834-01, Canada) following the manufacturer instructions. Concentrations of RNA were measured by spectrophotometry (OD $260 \mathrm{~nm}$ ), and RNA integrity was electrophoretically verified using ethidium bromide. After DNAse treatment (Ambion, Clinisciences, Montrouge, France), RNA was reverse transcribed using Super Script II RNase H Reverse Transcriptase (Invitrogen, Carlsbad, CA, USA) in the presence of Random Primers (Promega, Charbonnièresles- Bains, France). Polymerase chain reaction (PCR) was performed using a 2720 thermocycler (Applied Biosystems, USA). Using PCR master mix (Qiagen USA) following the manufacturer instructions and using the specific primers for SOD "forward 5'-GGTGCCCTGGAGCCCTA-3' and reverse 5'-ATGCGAAGTCTTCCACTGTC-3 and for CAT "forward 5'-TCCTGAATGAGGAGGAGCGA-3' and reverse 5'-ATCTTAGATGAGGCGGTGATG-3', primer were designed using primer 3 programme based on the published nucleotide sequence information of the $O$. niloticus SOD and CAT genes (GenBank accession no. JF801727.1 and JF801726.1 ), PCR conditions were a denaturation at $95{ }^{\circ} \mathrm{C}$ for 2 min followed by 28 cycles of $95^{\circ} \mathrm{C}, 1 \mathrm{~min} ; 55^{\circ} \mathrm{C}, 1 \mathrm{~min} ; 72^{\circ} \mathrm{C}, 1 \mathrm{~min}$. PCR products were analyzed on a $2 \%$ agarose gel in $90 \mathrm{mM}$ Trisborate, $2 \mathrm{mM}$ EDTA buffer (TBE), pH 8, and visualized by staining with ethidium bromide and UV transillumination, For quantitative evaluation, absolute optical densities (OD) of RT-PCR signals were obtained by densitometric scanning using an image analysis system (1-D Manager; TDI Ltd.). The values for the specific targets were normalized according to those of GAPDH to express arbitrary units of relative abundance of the specific messages (i.e., relative expression).

\section{Statistical analysis:}

The data was statistically analyzed by SPSS version 20 (SPSS, Richmond, USA) was used as described by Dytham, 1999). Statistical packages (IBM 1 New Orchard Road Armonk, New York 10504-1722 United States), and presented as a mean $\pm \mathrm{SD}, \mathrm{n}=10$. Statistical differences between groups performed using One-way analysis of variance (ANOVA). Duncan's test was used for testing the inter-grouping homogeneity (Duncan 1995). Statistical significance was set $\mathrm{P} \leq 0.05$ and $\mathrm{P} \leq 0.01$.

\section{RESULTS}

This work was designed to investigate the toxic effects of three different concentrations (1/3, 1/10 and $1 / 20$ of $\mathrm{LC}_{50}$ ) of tea seed cake on $O$. niloticus through monitoring their effects on functional and histological of both liver and kidney, our results revealed that all used concentrations were toxic and the degree of toxicity related to the concentrations. The toxicity was manifested by increasing significantly $(\mathrm{P} \leq 0.05 ; \mathrm{P} \leq 0.01)$ the concentrations of liver and kidney biochemical markers; serum ALT, creatinine and urea concentrations as well as the induction of the activities of the antioxidant enzymes; SOD and CAT. In both liver and kidney tissue (Table 1) on a molecular level there are induction of the gene expression of SOD and CAT genes in liver and kidney tissues (Fig. 3). The histological examination of both kidney and liver tissues confirmed the biochemical and molecular results and reveled that, the hepatopancreatic tissue showed a severe vacuolization with pyknotic nuclei and intravascular hemolysis, necrosis with lymphocytes and EGCs infiltrations and hemosiderosis that stained blue by Prussian blue stain at the 1/3 LC50 concentration (Fig $1 \mathrm{~B}, \mathrm{C}$ and D), but with $1 / 10 \mathrm{LC}_{50}$; a moderate vacuolization in the hepatocytes and intravascular hemolysis were occured (Fig. 1 E) finally with $1 / 20$ $\mathrm{LC}_{50}$; a centrolobular hydropic degeneration with 
pyknotic nuclei and mild intravascular hemolysis were manifested (Fig $1 \mathrm{~F}$ ). In relation to kidney tissue it had a severe hydropic degeneration and vacuolization in the tubular epithelia with few round cells infiltration, focal coagulative necrosis and basophilic calcification that stained black by Von Kossa stain ( Fig 2 B,C and D), in
$1 / 3$ LC50, with $1 / 10 \mathrm{LC}_{50}$ a vacuolization in the renal epithelia and intravascular hemolysis, lymphocytes aggregations around necrotic renal tubules were reveled (Fig. $2 \mathrm{E}$ and $\mathrm{F}$ ), the same pathological manifestation were seen with $1 / 20 \mathrm{LC}_{50}$ but in a low degree with thickening of tunica media ( Fig $2 \mathrm{G}$ ).

Table (1): Effect of tea seed cake on hepatic and renal function tests and tissue antioxidant enzymes activities.

\begin{tabular}{|c|c|c|c|c|}
\hline Parameters & $\begin{array}{c}\text { Control } \\
\text { group }\end{array}$ & $\begin{array}{c}1 / 3 \mathrm{LC}_{50} \\
\text { group }\end{array}$ & $\begin{array}{l}1 / 10 \mathrm{LC}_{50} \\
\text { group }\end{array}$ & $\begin{array}{c}1 / 20 \mathrm{LC}_{50} \\
\text { group }\end{array}$ \\
\hline $\operatorname{ALT}(\mathrm{U} / \mathrm{ml})$ & $55.77 \pm .604$ & $75.02 \pm .663^{*}$ & $65.24 \pm 1.08^{*}$ & $55.13 \pm 1.09$ \\
\hline Creatinine (mg/dl) & $0.330 \pm .009$ & $0.832 \pm 019^{*}$ & $0.715 \pm .028^{*}$ & $0.340 \pm .010$ \\
\hline Urea (mg/dl) & $6.15 \pm .239$ & $10.54 \pm 396^{*}$ & $9.12 \pm .225^{*}$ & $7.20 \pm .543$ \\
\hline Hepatic SOD (ug/g tissue) & $0.81 \pm 0.024$ & $1.13 \pm 0.042^{* *}$ & $1.02 \pm 0.039^{*}$ & $0.852 \pm 0.029^{*}$ \\
\hline Renal SOD (ug/g tissue) & $068 \pm 0.019$ & $0.94 \pm 0.031^{* *}$ & $0.85 \pm 0.029^{*}$ & $0.71 \pm 0.02^{*}$ \\
\hline Hepatic САТ $\left(\mu \mathrm{M} \mathrm{H}_{2} \mathrm{O}_{2}\right.$ decomposed/g tissue $)$ & $1.03 \pm 0.030$ & $1.65 \pm 0.017^{*}$ & $1.42 \pm 0.009^{* *}$ & $1.09 \pm 0.021$ \\
\hline Renal CAT $\left(\mu \mathrm{M} \mathrm{H} \mathbf{H}_{2} \mathrm{O}_{2}\right.$ decomposed $/ \mathrm{g}$ tissue $)$ & $0.86 \pm 0.02$ & $1.38 \pm 0.01^{* *}$ & $1.18 \pm 0.006^{*}$ & $0.91 \pm 0.018^{*}$ \\
\hline
\end{tabular}

Means within the same raw carrying different astrics are significant at $\mathrm{P}<0.05^{*}$ and $\mathrm{P}<0.01^{*}$
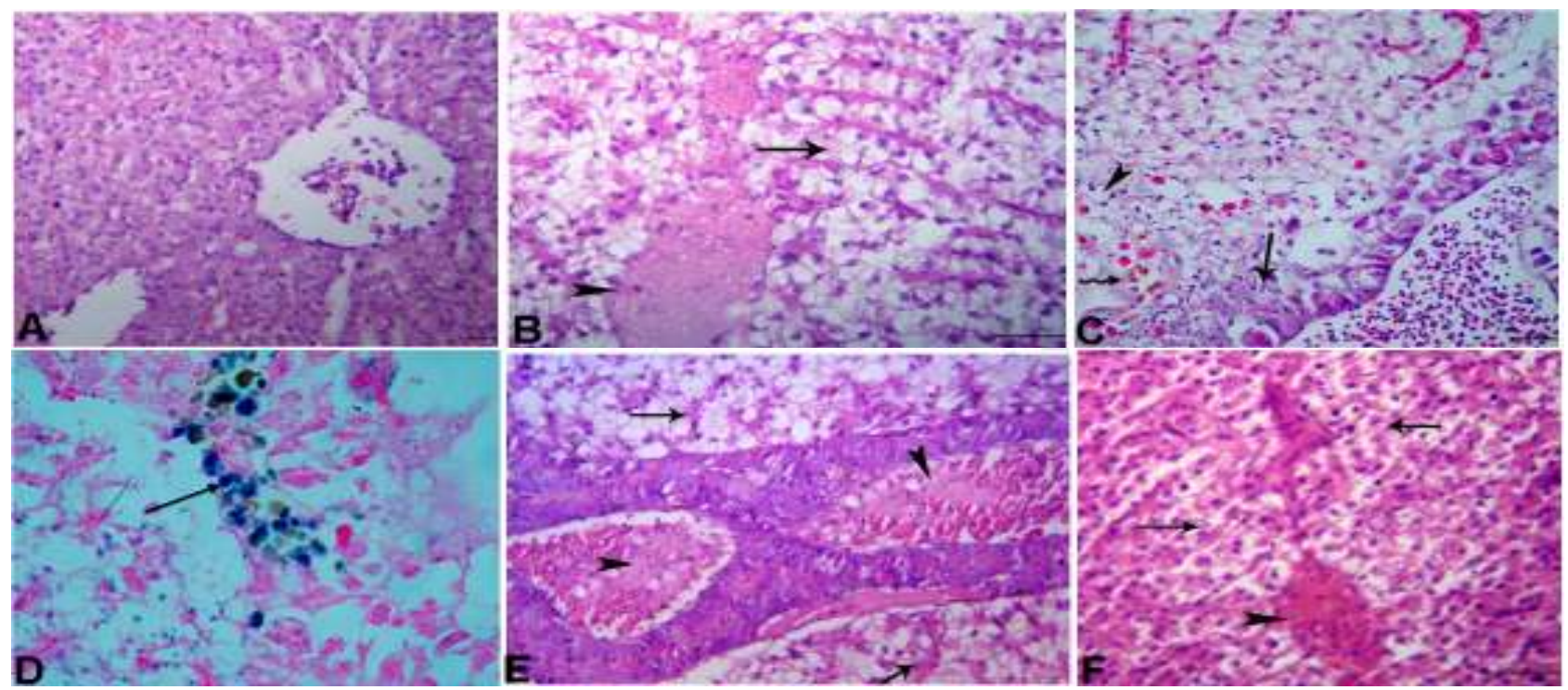

Figure (1): Control liver A, 1/3 LC 50 ( B,C and D) Liver shows severe vacuolization with pyknotic nuclei (arrow) and intravascular hemolysis (arrowhead) B, hepatopancreatic necrosis (arrow) with lymphocytes and EGCs infiltrations (arrowhead), and hemosiderosis (zigzag arrow) C. Liver shows hemosiderosis stained blue (arrow) by Prussian blue stain D. 1/10 $\mathrm{LC}_{50}$; Liver shows moderate vacuolization in the hepatocytes (arrows) and intravascular hemolysis (arrowheads) E, 1/20 LC $\mathrm{LC}_{50}$, Liver shows centrolobular hydropic degeneration with pyknotic nuclei (arrows) and mild intravascular hemolysis (arrowhead) F. HE $($ Bar $=$ $100 \mu \mathrm{m})$. 

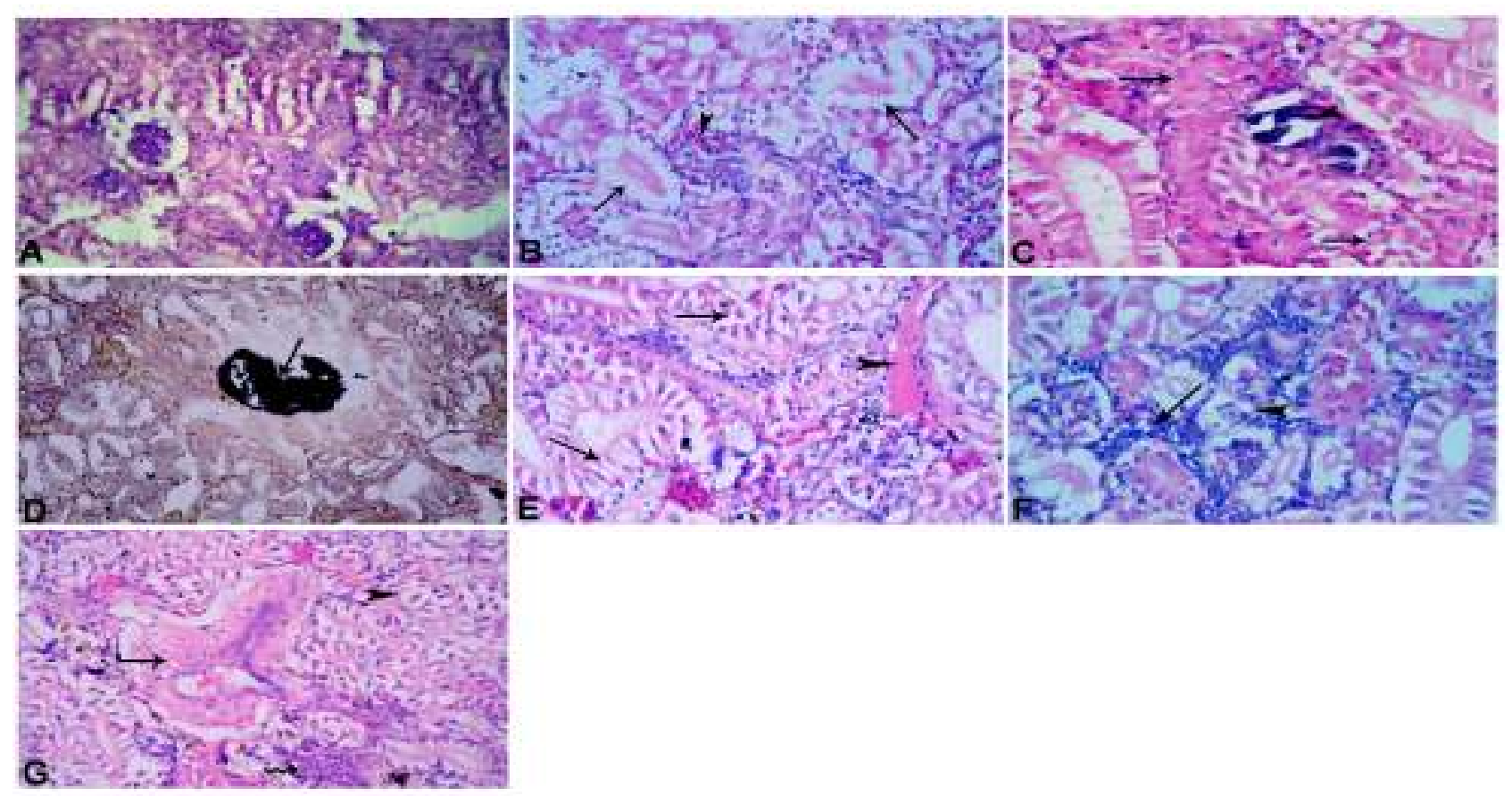

Figure (2): Control kidny A, 1/3 $\mathrm{LC}_{50}$ ( B,C and D) Kidney shows severe hydropic degeneration and vacuolation in the renal tubular epithelia (arrows) and few round cells infiltration (arrowhead) B, Kidney shows focal coagulative necrosis (arrows) and basophilic calcification (arrowhead) C, Kidney shows calcification stained black by Von Kossa stain (arrow) D. 1/10 LC L $_{50}$ Kidney shows vacuolation in the renal epithelia (arrows) and intravascular hemolysis (arrowhead) E, lymphocytes aggregations (arrow) around necrotic renal tubules (arrowhead) F. 1/20 LC 50 Kidney shows vacuolation in the renal epithelia (arrowhead), intravascular hemolysis with thickening and vacuolation of tunica media (arrow) and few lymphocytes aggregation (zigzag arrow) G. $\mathrm{HE}(\mathrm{Bar}=100 \mu \mathrm{m})$.
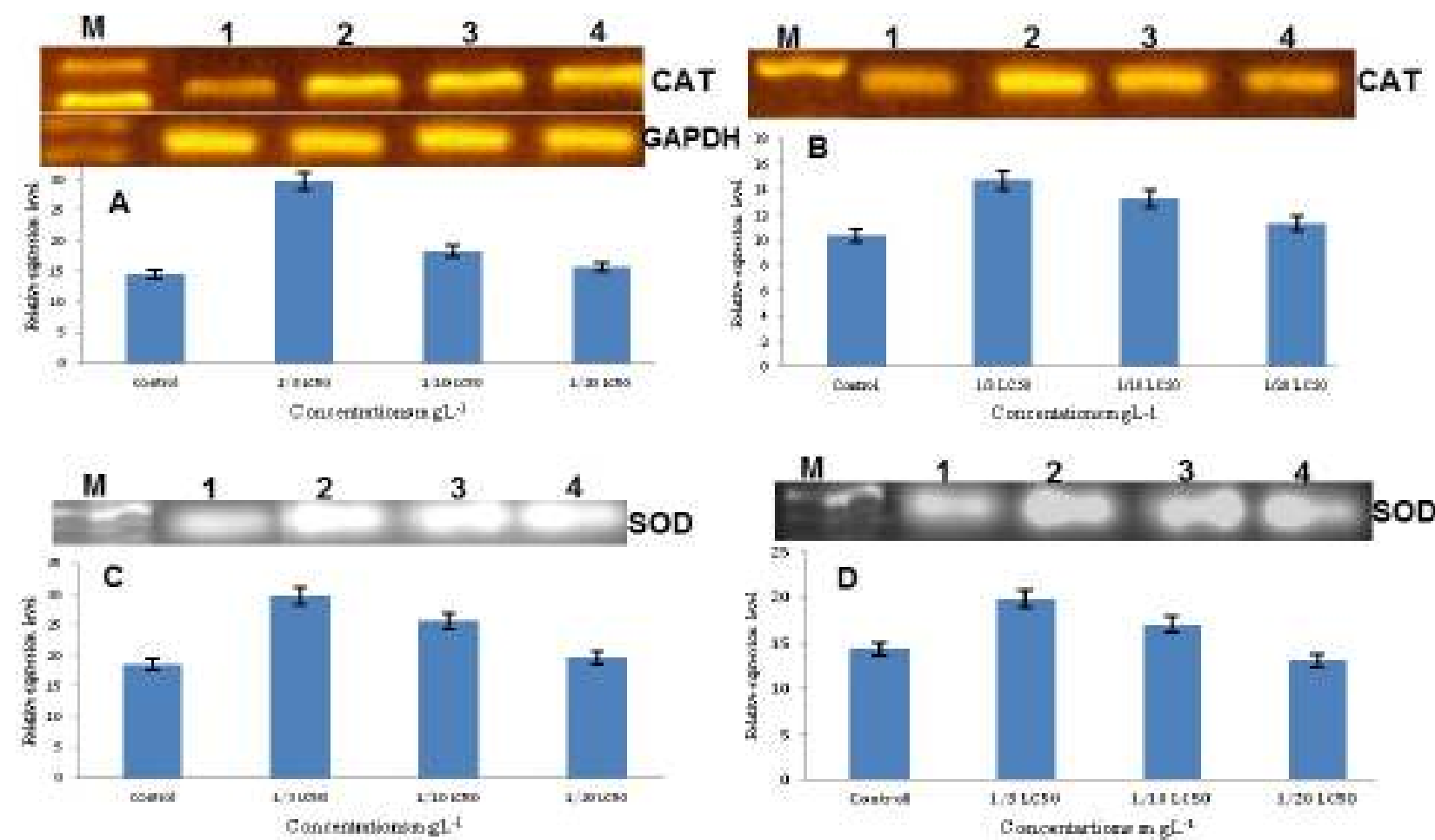

Figure (3): Gene expression of hepatic and renal catalase gene A and B, and hepatic and renal SOD C and D expressed as a relative expression to GAPDH. 


\section{DISCUSSION}

Tea seed cake is botanical pesticides could be extensively used in aquaculture to eliminate predatory fishes in fish and prawn ponds. It also widely used in killing snails in pond or coastal cropland, earthworms in vegetable field and underground pests in golf grassland. It can help shrimp exuviate and improve the quality of water. It not left contamination and poison through hydrolyzing process in pond still crude protein and crude fiber, which can be assimilated thoroughly by aquatic creatures and algae bloom. Tea seed cake produced from Camellia $s p$. seeds after oil extraction it contains many active principles especially saponin which represent $5.2 \%-7.2 \%$. It has many toxicological effects on fish especially when be used in large concentrations. Our results indicated various levels of toxicity on $O$. niloticus fingerlings with respect to the different concentrations $1 / 3,1 / 10$ and $1 / 20$ of $\mathrm{LC}_{50}$. On the serum level there was a high increase of liver and kidney toxicity biomarker ALT, creatinine and urea in fishes subjected to $1 / 3 \mathrm{LC}_{50}$ (Table 1), this may be due to the distraction that occurred in liver and kidney cells as seen in heistopathological examinations which revealed a severe vacuolization and necrosis of hepatocyt (Fig. 1B, C and D), Kidney shows severe hydropic degeneration and vacuolization in the renal tubular epithelia and few round cells infiltration, focal coagulative necrosis and basophilic calcification (Fig.2 $\mathrm{B}, \mathrm{C}$ and D) the concentration of the biochemical markers (ALT, creatinine and urea) were decreased gradually thorough decreasing of tea seed cake concentration $1 / 10$ and $1 / 20 \operatorname{LC}_{50}$ ( Table 2) but still significantly increased when compared with control samples, the improvement of serum hepatic and renal biomarkers concentration may be due to the moderate effect of tea seed cake on hepatocyt which manifested by moderate vacuolization and degeneration (Fig $1 \mathrm{E}$ and F), Kidney shows moderate vacuolization and necrosis in the renal epithelia (Fig. 2 E, F and G). The toxic effect of tea seed cake may be explained by it's high level of saponin. The toxic effect of saponin of Quillaja saponaria that manifested by the increase of serum ALT and the histological observations showed hepatocyte injures, hypertrophy, cloudy swelling and vacuolization with architectural disarray, hepatic cell degeneration, kidney tubule necrosis with hemolytic erythrocytes in the hematopoietic tissue appeared (Vinay et al., (2013). In rat saponins mixture revealed mild cytolysis of the hepatocytes affecting predominantly the periportal region, nuclear vacuolation and prominent nuclei and sinusoidal congestion hepatocytes architectural disarray with extensive necrosis, kidney showed focal tubular atrophy and necrosis with epithelial cells vacuolation and tubular necrosis (Akinpelu et al., 2012) other investigators have reported untoward histopathological changes in rat /mice tissues following ingestion of saponin containing substances (Hostettmann and Marston 1995, Gee et al., 1993 and Gee and Johnson, 1988) changes observed in transaminases activities in liver and plasma of rats was speculated to be a reflection of liver damage occasioned by ingestion of saponin while the increase of plasma creatinine and urea might be due to kidney damage (Akinpelu et al., 2012). Mice ingested saponins had a hepatotoxic lesions that manifested by small hemorrhage in many hepatic lobules, congestion of central veins and sinusoid, distraction of liver architecture and hepatic necrosis as well destruction of renal tubular cells and hemorrhage (Diwan et al., 2000).

CAT gene expression and activities in liver and kidney tissues of fish exposed to tea seed cake were found to be higher than in control fish (Table 1 and figure 3). The stimulation of CAT gene expression and activities were clearly concentration dependant, it increased in response to $1 / 10$ and $1 / 20 \mathrm{LC}_{50}$ of toxin but the increase was most pronounced in fish exposed to the highest concentration of toxin $\left(1 / 3 \mathrm{LC}_{50}\right)$. CAT is an enzyme that is known to detoxify reactive oxygen species in the cells. The increase of gene expression and activity of the CAT in fish in response to tea seed cake most probably occurs in response to an increase of reactive oxygen species indicating an oxidative stress in the animal in response to the toxin. The hepatic and renal SOD activities and gene expression were higher in fish exposed to tea seed cake than in control fish (Table 1 and figure 3 ) this increase is a concentration dependant. The increase in SOD activities and gene expression may be explained as a response to the toxic effect of tea seed cake on both liver and kidney tissues which may be induced the super oxide radicals generation. As with other animals, fish have antioxidant defense mechanisms, which help to maintain health and prevent oxidation lesions. SOD and CAT are important antioxidant enzymes (Halliwell and Guterridge, 2000; Tocher et al.,_2002). The enzymes are commonly used in toxicological tests as stress indicators (Esterbauer and Cheesman, 1991). SOD and CAT are scavengers of the reactive oxygen species, acting on superoxide $\left(\mathrm{O}^{-}\right)$and hydrogen peroxide $\left(\mathrm{H}_{2} \mathrm{O}_{2}\right)$ respectively (Tocher et al., 2002).

\section{CONCLUSIONS}

In conclusion, it is believed that the used reliability of histopathological lesions, ALT, SOD and CAT as biomarkers of stress in fish under long term exposure to tea seed cake.

\section{REFERENCES}

Abei, H., 1984. Determination of Malondialdehyde. Method Enzymol. 105: 121-126.

Akinpelu, B.A.O., Oluookun, O. I., and Ezekiel, O. F., 2012. Biochemical and histopathological profile of toxicity induced by saponin fraction of Erythrophleum suaveolens (Guill. and Perri.) bark extract. Phytopharmacology, 3(1): 38-53.

Bancroft, J.D., and Gamble, M., 2008. Theory and Practice of Histological Techniques. $5^{\text {th }}$ ed., Churchill Livingstone. New York, London, Philadelphia.

Bhatia, H.L., 1970. Use of Mahua oil cake in fishery management. Indian Farming 20: 39-40.

Cagauan, A. G., 1995. The impact of pesticides on rice field vertebrates with emphasis on fish. pp. 203 248. In: P. L. Pingali and P. A. Roger (eds.). 
Impact of Pesticides on Farmer Health and the Rice Environment. International Rice Research Institute. Kluwer Academic Publishers. 664 pp.

Chakroff, M., 1976. In: Fresh water fishpond culture and management. A joint Peace Corps and volunteers in Technical Assistance Publication, MD

Chaney, A., and Marbach, E., 1962. Modified reagents for determination of urea and ammonia. Clin. Chem. 8:130.

Chen, J.C, Chen, K.W., and Chen, J.M., 1996. Effects of saponin on survival, growth, molting and feeding of Penaeus japonicas juveniles. Aquaculture 144: 165-175.

Chen, J.C., and Chen, K.W., 1996. Hemolymph oxyhemocyanin, protein levels, acid-base balance, and ammonia and urea excretions of Penaeus japonicus exposed to saponin at different salinity levels. Aquat Toxicol 36: 115-128.

Dahiya, S., Kaur, A., and Jain, N., 2000. Studies on difluoridation of water with Eichornia plant. Journal of Environmental Biology 21 (4): 337340.

De DK, Nath, D., and Sen, P.R., 1987 Preliminary studies on tea seed-cake as a fish toxicant. Indian J Anim Sci. 57: 781-783.

De la, Higuera, M., Garcia-Gallego, M., Cardenete, G., Suarez, M.D., and Moyano, F.J., 1988 Evaluation of Lupin seed meal as an alternative protein source in feeding of rainbow trout Salmo gairdneri . Aquaculture 71:37-50.

Diwan, F.H., Abdel-Hassn, I.A., and Mohammed, S.T., 2000. Effect of saponin on mortality and histopathological changes in mice. Eastern Mediterranean health journal 6 (2/3): 345-351.

Duncan, D.B. (1955). Multiple Range and Multiple Ftest. Biometrics, 11: 1-42.

Dytham, C. (1999). Choosing and using statistics: A Biologist's guide. Blackwell Science Ltd., London, United Kingdom.

Esterbauer, H.,and Cheesman, K.H., 1991. Determination of aldehyclipid peroxidation products: malonal dehydeand4-Hydroxynonenal. In: Parker, L., Glazer, A. (Eds.), Methods in Enzymology, vol. 186B. Academic Press, New York, pp. 407-421.

Fenwick, G.R., Price, K.R., Tsukamoto, C., and Okubo, K., 1991. Saponins. In: D’Mello, F.J.P., Duffus, C.M., Duffus, J.H. Eds., Toxic Substances in Crop Plants. The Royal Society of Chemistry, Thomas Graham House, Science Park, Cambridge CB4 4WF, Cambridge, pp. 285-327.

Gee, J.M., and Johnson, I.T., 1988. Interactions between haemolytic saponins, bile salts and small intestinal mucosa in the rat. Journal of Nutrition 118: 1391-1397.

Gee, J.M., Price, K.R., Ridout, C.L., Wortley, G.M,, Hurrell, R.F., and Johnson, I.T., 1993. Saponins of quinoa (Chenopodium quinoa): effects of processing on their abundance in quinoa products and their biological effects on intestinal mucosal tissue. Journal of the Science of Food and Agriculture 6: 201-209.
Halliwell, B., and Gutteridge, J.M., 2000. Free Radical in Biology and Medicine, 3rd ed. Oxford Univ. Press. 936 pp.

Hostettmann, K., and Marston, A., 1995. Chemistry and pharmacology of Natural products. Cambridge University Press, Cambridge, 284-286.

Husdan, H., and Rapoport, A., 1968. Estimation of creatinine by Jaffe reaction. A comparison of three methods. Clin Chem, 14: 222-238.

Istvan, U., 2000. Semi-natural products and related substances as alleged botanical pesticides. Pest Management Science. 56: 703-705.

Kulakkattolickal, A.T., 1989. Pesticidal plants of Nepal: Toxicity to air breathing predatory fish (Ophicephalus puctatus, Clarias batrachus and Hetropneustes fossilis) and the duration of risk to cultivated fish. Aquaculture 78: 285-292.

Marston, A., and Hostettmann, K., 1985. Plant molluscicides. Phytochemistry 24: 639-652.

Meadus, W.J., 2003. A semi- Quantitative RT-PCR method to measure the in vivo effect of dietary conjugated linoleic acid on protein muscle PPAR gene expression. Biol. Proced. On line 5: 20-28.

Minsalan, C.O., and Chiu, Y.N., 1986. Effects of tea seed cake on selective elimination of finfish in shrimp ponds. In: Maclean, J.L., Dizon, 1.B., Hosillos, L.V. (Eds.), The First Asian Fisheries Forum. Asian Fisheries Society, Manila, Philippines, pp. 79-82.

Packer, L., and Glazer, A.N., 1990. Method in enzymology. Vol. 186 part B, Academic press Inc. New York, PP. 251.

Reitman, S., and Frankel, S., 1957. A colorimetric method for the determination of glutamic oxaloacetic and glutamic pyruvic transaminases. Amer. J. Clin. Pathol. 28-56.

Sommai C., Niti R., Manoj H., and Pichaet W., 1997. Toxicity of the Thai piscicidal plant, Maesa ramentacea, to freshwater fishes in ponds. Aquaculture 158, 229-234.

Terazaki, M., Tharnbuppa, P., and Nakayama, Y., 1980. Eradication of predatory fishes in shrimp farms in utilization of Thai tea seed. Aquaculture 19: 235242.

Tocher, D.R., Mourente, G., Van, Der., Eecken, A., Evjemo, J.O., Diaz, E., Bell, J.G., Geurden, I., and Olsen, Y., 2002. Effects of dietary vitamin E on antioxidant defence mechanisms of juvenile turbot (Scophthalmus maximus L.), halibut (Hippoglossus hippoglossus L.) and sea bream (Sparus aurata L.). Aquac Nutr 8: 195-203.

Vinay ,T.N., Chang-Su, P., Heung-Yun, K., and SungJu, J., 2013. Toxicity and dose determination of quillaja saponin, aluminum hydroxide and squalene in olive flounder (Paralichthys olivaceus).Vet. Immunol Immunopathol (in press).

Yousif, O.M., Alhadhrami, G.A.,and Pessarakli, M., 1994. Evaluation of dehydrated alfalfa and salt bush Atriplex leaves in diets for tilapia Oreochromis aureus L. Aquaculture 126: 341347. 